\title{
Genetic structure of natural and restored shoalgrass Halodule wrightii populations in the NW Gulf of Mexico
}

\author{
Steven E. Travis ${ }^{1, *}$, Pete Sheridan ${ }^{2}$ \\ ${ }^{1}$ US Geological Survey National Wetlands Research Center, 700 Cajundome Boulevard, Lafayette, Louisiana 70506, USA \\ ${ }^{2}$ US Department of Commerce, NOAA, National Marine Fisheries Service, Southeast Fisheries Science Center, \\ 3500 Delwood Beach Road, Panama City Beach, Florida 32408, USA
}

\begin{abstract}
The decline of seagrass communities worldwide has sparked an urgent need for effective restoration strategies, which require a working knowledge of population genetic structure. Halodule wrighti is a common seagrass of the Caribbean region that is being restored to areas of the Gulf of Mexico, yet little is known of its population genetics. This study provides an assessment of individual, clonal and population effects on the genetic structure of 4 natural $H$. wrightii populations occupying $170 \mathrm{~km}$ of coastline in and around Galveston Bay, Texas, for comparison with 7 restored populations ranging in age from 2 to $7 \mathrm{yr}$. By using molecular markers, in the form of amplified fragment length polymorphisms (AFLPs), we found considerable variation in clonal richness at the population scale (from 0.54 to 0.82 ), with the restored populations occupying an intermediate to high position within this range. Replicate sampling within individual seagrass beds of 3 to $5 \mathrm{~m}$ diameter generally revealed higher levels of clonal richness, elevated by 4 to $22 \%$ over that at the population scale, suggesting that seed recruitment is more important at the local scale than at distances of $>10 \mathrm{~m}$. Genetic diversity was 2 to 3 times less than that expected for a widespread, outcrossing species like $H$. wrightii, although a $170 \%$ increase in the frequency of variable markers relative to the mean for all other populations was noted for a volunteer population that had recruited from a mixture of donor materials planted at a nearby restoration site. Within the spatial extent of this study, natural populations adhered to a model of isolation-by-distance, whereas donor materials from these same natural populations were undergoing a rapid genetic convergence within a restored site where they had been planted together.
\end{abstract}

KEY WORDS: Seagrass $\cdot$ Halodule wrightii $\cdot$ Genetic structure $\cdot$ Clonal reproduction · Genetic diversity $\cdot$ Amplified fragment length polymorphism $\cdot$ Gulf of Mexico

\section{INTRODUCTION}

Some of the world's most productive ecosystems occupy the coastal zone of tropical and sub-tropical land masses (Lieth \& Whittaker 1975, Kennish 1986), yet land development, dredging activities and chemical pollutant discharges pose severe threats to these systems, sparking a growing interest in habitat restoration activities. While it is generally accepted that the restoration of coastal communities begins with the reestablishment of primary producers which can act as ecosystem engineers (Kusler \& Kentula 1989), it is often less certain where best to obtain plant materials for restoration. Central to this question is the issue of population genetic structure, because it helps to determine both the level of pre-adaptation of donor materials to a particular restoration site (Krauss \& Koch 2004 and references therein), and whether they are likely to harbor sufficient genetic diversity to evolve in response to environmental challenges and to avoid the harmful effects of inbreeding (Montalvo et al. 1997). Because many of the plant species that form the foundation for coastal communities, such as emergent marsh grasses and seagrasses, are characterized by 
vegetative or clonal propagation, an additional concern is the clonal diversity of the donor materials (Zedler 2000). Ignoring this aspect of population genetic structure could lead to the development of donor materials that are suitable from an adaptive perspective, but that consist of so few genetically distinct individuals that inbreeding becomes an issue (Travis et al. 2004).

Seagrasses form the basis of many highly productive coastal ecosystems, and are particularly noted for their capacity to provide critical nursery habitat for fishes and decapod crustaceans (Hemminga \& Duarte 2000, Heck et al. 2003). Seagrasses also tend to be relatively fragile habitats that are easily disturbed by human activities such as dredging and nutrient addition, and seagrass losses have been noted around the globe (e.g. Short \& Wyllie-Echeverria 1996, Duarte 2002). As seagrass restorations get underway, the issue of clonal diversity is particularly important because seagrass meadows are so low in species diversity (Hemminga \& Duarte 2000) - with the seagrasses themselves forming the structural foundation for the community (Duarte 2002) - that clonal diversity (as opposed to plants species diversity; Schlapfer \& Schmid 1999) can become the primary driver of ecosystem productivity, resistance, and resilience (Hughes \& Stachowicz 2004, Reusch et al. 2005). Seagrass studies have also indicated that the heterozygosity of individual seagrass clones can affect performance, both in terms of growth (Procaccini \& Piazzi 2001, Williams 2001) and reproductive potential (Williams 2001). Thus, seagrass restoration projects should ideally incorporate strategies that promote the development of clonally diverse populations, represented by genetically diverse clones, with the potential to adapt to rapidly changing environments (Montalvo et al. 1997). Of course, it is also important to consider that seagrass clones are known to perform best under local environmental conditions (Hämmerli \& Reusch 2003), and that transplanting individuals between genetically differentiated populations should be avoided (van Andel 1998).

Considerable attention has been focused on the population genetic structure of several widely distributed seagrass species, particularly Zostera marina (e.g. Ruckelshaus 1998, Williams \& Orth 1998, Reusch et al. 1999, Williams 2001, Reusch 2002, Hämmerli \& Reusch 2003, Olsen et al. 2004, Muñiz-Salazar et al. 2005) and Posidonia oceanica (e.g. Procaccini et al. 1996, Procaccini \& Piazzi 2001, Jover et al. 2003). In contrast, little is known of the local or regional genetic structure of Halodule wrightii, a common inhabitant of shallow waters throughout the Caribbean region. Typical of seagrasses, $H$. wrightii is capable of both sexual and clonal recruitment, which occurs through extension and branching of the horizontal rhizome or through fragmentation and rafting of leaf and root material. Gene flow may be enhanced by positively buoyant leaves and rhizomes that make fragments subject to dispersal by currents. On the other hand, the production of negatively buoyant seeds under the sediment surface, which may only be transported via bioturbation or erosion, would tend to promote local genetic structure. Halodule wrightii is dioecious and thus immune to selfing, or uniparental inbreeding (Les 1988), but is still subject to biparental inbreeding.

Over 450 hectares of Halodule wrightii (and the associated seagrass species Thalassia testudinum) disappeared from the bay margin of western Galveston Island, Texas, between 1960 and 1982. This disappearance has been attributed to waterfront dredging, wastewater discharges, and unidentified pollution (Pulich \& White 1991, Hammerstrom et al. 1998). By the early 1990s water quality had improved and dredging impacts were minimized (Hammerstrom et al. 1998), thus setting the stage for natural and humanassisted revegetation by seagrasses. A number of restoration experiments conducted along western Galveston Island from 1993 through 2003 produced $H$. wrightii beds that remained viable as of April 2004 (Sheridan et al. 1998, 2003, P. Sheridan unpubl. data). In addition, as early as July of 1998, volunteer (i.e. naturally recruited) $H$. wrightii beds began appearing in the vicinity of the restored beds in an area known as Redfish Cove along western Galveston Island. These new beds were usually circular in appearance, indicating that they probably originated from just 1 or a few fragments or seeds (collectively termed 'propagules'). Volunteer beds could be derived from sexual or asexual propagules transported from planted materials at Redfish Cove or elsewhere in Galveston Bay, from a naturally occurring seagrass meadow in nearby Christmas Bay, or from waters flowing into Galveston Bay from the adjacent Gulf of Mexico (see Fig. 1).

Here we provide information on several key attributes of the population genetic structure of Halodule wrightii. Specifically, this study assessed individual, clonal and population effects on the genetic structure of natural $H$. wrightii populations in this region for comparison with a series of restorations ranging in age from 2 to $7 \mathrm{yr}$, by using molecular markers in the form of amplified fragment length polymorphisms (AFLPs). This information will begin to reveal the factors behind the short-term success of the Galveston Bay restoration program so that they can be considered in the formulation of future restorations, and will shed needed light on the potential for long-term persistence of both natural and restored $H$. wrightii populations in this region, particularly in reference to possible future disturbances. 


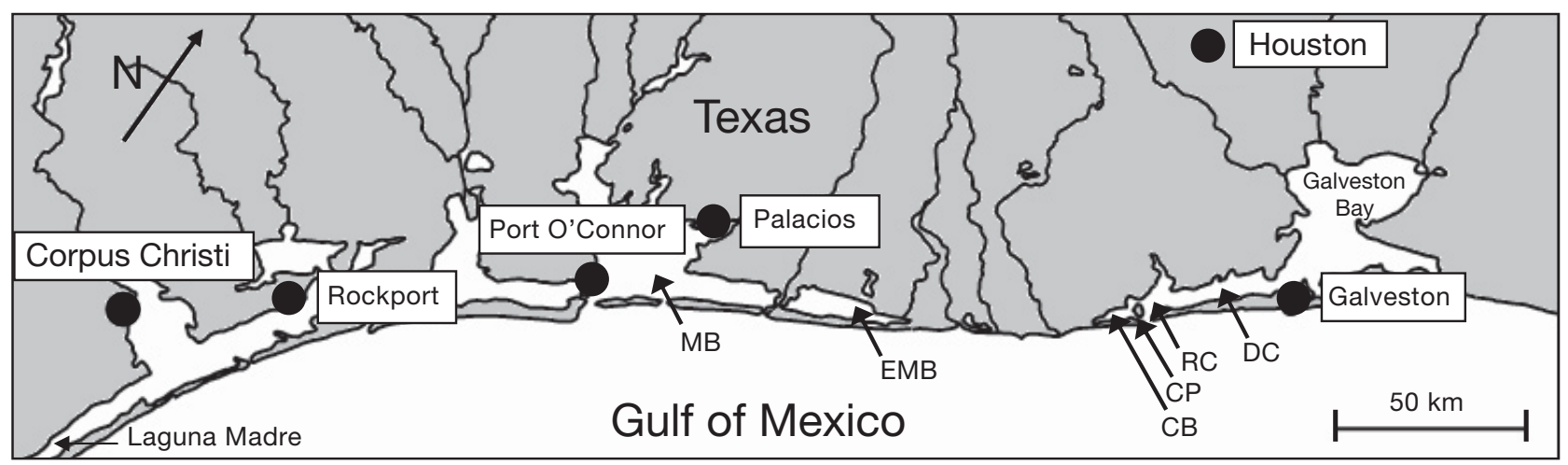

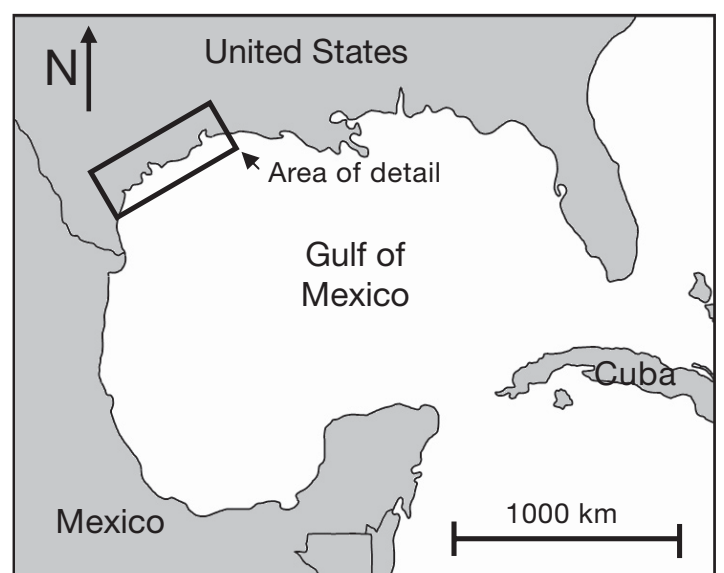

\section{MATERIALS AND METHODS}

Site description and sampling of Halodule wrightii. Our sampling efforts spanned a $170 \mathrm{~km}$ range of coastline along the NW Gulf of Mexico, from which we sampled 7 sites (Fig. 1). Of these sites, 4 (Cold Pass, Christmas Bay, East Matagorda Bay and Matagorda Bay near Port O'Connor) consisted of natural seagrass meadows occupying a series of sheltered bays and channels to the SW of Galveston Bay. Each of these meadows was treated as a population, with sampling activities conducted over a suitably broad area to encompass a representative proportion of the genetic diversity present (see following subsection). The other 2 sites (Redfish Cove and Dana Cove) were located in Galveston Bay and consisted of restored seagrass meadows established using donor materials from 5 and 3 separate donor sites, respectively (Table 1; Fig. 2). The largest restored meadow was sampled at Redfish Cove located near the SW tip of Galveston Island. In 1994, this site was planted with donor material from a natural meadow located in Matagorda Bay near Palacios (Sheridan et al. 1998), followed in 1999 by 4 additional plantings using materials from both the earlier 1994 planting and 3 of the 4 natural meadows described
Fig. 1. NW Gulf of Mexico, indicating 6 site locations where 11 natural and restored populations of Halodule wrightii were sampled for this study. CB: Christmas Bay; CP: Cold Pass, DC: Dana Cove; EMB: East Matagorda Bay; MB: Matagorda Bay; RC: Redfish Cove. A seventh site 'volunteers' was located several hundred meters from $\mathrm{RC}$ and is not included on the map

above (excluding Cold Pass because of its small size; Sheridan 2002a). For both the 1994 and 1999 plantings, donor materials were taken haphazardly across the entire length and width of each donor population in order to maximize potential genetic diversity, with the exception of Christmas Bay, where government regulations limited the collections to eight $4 \mathrm{~m} \times 4 \mathrm{~m}$ plots. Because all donor materials were kept segregated by donor site during transplantation, we were able to sample from each separate planting, treating each as a distinct population. The other restored meadow, Dana Cove (18 km NE of Redfish Cove), was planted between 1995 and 2000 from donor materials representing 3 natural meadows, although only 1 of these plantings (from Laguna Madre $300 \mathrm{~km}$ to the southwest) survived. Thus, we sampled this meadow as a single population. The final site consisted of a naturally recruited, or 'volunteer' meadow located near Redfish Cove (Fig. 2), which was composed of roughly 90 distinct seagrass beds at the time of sampling. Locations of successful (and unsuccessful) restorative plantings are known from permanent or semipermanent markers and global positioning system (GPS) readings (Hammerstrom et al. 1998, Sheridan et al. 1998, Sheridan 2002a, Galveston Bay Foundation 2003).

Materials for genetic analyses were collected during 2001 and 2002 (for sample sizes see Table 2). The seagrass meadows at our 4 natural sites were continuously distributed, while our restored and volunteer populations consisted of scattered beds of varying sizes. Our sampling scheme was designed to include both a representative number of sampling units from each population, equivalent to beds where meadows were patchily distributed (and hereafter referred to as beds), and a representative number of ramets from each bed 
Table 1. Halodule wrightii. Seagrass restorations in West Bay (part of the Galveston Bay system) from SE Texas. Names of cities nearby in parentheses. Distance: distance between restoration and donor sites. Root: shoots and roots only; Plug: shoots, roots and sediment; Debris: seagrass debris from power plant intake screen. Restoration status is denoted by asterisks $\left({ }^{* *}=\right.$ known success; ${ }^{*}=$ probable success). Unpublished data courtesy of B. Pridgeon and W. Roach, US Fish and Wildlife Service, Houston, Texas

\begin{tabular}{|c|c|c|c|c|c|}
\hline $\begin{array}{l}\text { Restoratio } \\
\text { site }\end{array}$ & $\begin{array}{l}\text { Donor } \\
\text { site }\end{array}$ & $\begin{array}{l}\text { Distance } \\
(\mathrm{km})\end{array}$ & $\begin{array}{l}\text { Planting } \\
\text { method }\end{array}$ & Month/year & Source \\
\hline \multirow[t]{6}{*}{$\begin{array}{l}\text { Redfish } \\
\text { Cove }\end{array}$} & Christmas Bay & 9 & \multicolumn{2}{|l|}{ Root, plug } & $\begin{array}{l}\text { Hammerstrom } \\
\text { et al. (1998) }\end{array}$ \\
\hline & Christmas Bay & 9 & Plug & $7 / 98^{* *}-8 / 99^{* *}$ & $\begin{array}{l}\text { Sheridan (2002a, } \\
\text { unpubl. data) }\end{array}$ \\
\hline & $\begin{array}{l}\text { Matagorda Bay } \\
\text { (Palacios) }\end{array}$ & 130 & Plug & $4 / 94^{* *}$ & $\begin{array}{l}\text { Sheridan } \\
\text { et al. (1998) }\end{array}$ \\
\hline & $\begin{array}{l}\text { East Matagorda } \\
\text { Bay }\end{array}$ & 85 & Plug & $5 / 99^{* *}-8 / 99^{* *}$ & Sheridan (2002a) \\
\hline & $\begin{array}{l}\text { Matagorda Bay } \\
\text { (Port O'Connor) }\end{array}$ & 150 & Plug & $5 / 99^{* *}-8 / 99^{* *}$ & $\begin{array}{l}\text { Sheridan } \\
(2002 a)\end{array}$ \\
\hline & Cold Pass & 3 & Plug & $2 / 02^{* *}-6 / 03^{* *}$ & $\begin{array}{l}\text { Galveston Bay } \\
\text { Foundation (2003) }\end{array}$ \\
\hline \multirow[t]{3}{*}{$\begin{array}{l}\text { Dana } \\
\text { Cove }\end{array}$} & $\begin{array}{l}\text { Laguna Madre } \\
\text { (Corpus Christi) }\end{array}$ & 270 & Debris & $12 / 95^{*}$ & $\begin{array}{l}\text { B. Pridgeon } \\
\text { (unpubl. data) }\end{array}$ \\
\hline & $\begin{array}{l}\text { Redfish Bay } \\
\text { (Rockport) }\end{array}$ & 230 & Root & $\begin{array}{c}5,9 / 97 ; 7 / 98 \\
6,8,12 / 99\end{array}$ & $\begin{array}{l}\text { W. Roach } \\
\text { (unpubl. data) }\end{array}$ \\
\hline & Laguna Madre & 270 & Plug & $9 / 00$ & Sheridan (2002b) \\
\hline
\end{tabular}

(Table 2). At our natural sites, a bed was simply defined as a 3 to $5 \mathrm{~m}$ diameter area haphazardly located within the larger seagrass meadow. Sampling within beds was also haphazard. Sampled beds were located in order to standardize their spacing within sites as much as possible (minimum spacing was approximately $10 \mathrm{~m}$ ), and were sampled at up to $4 \mathrm{sep}$ arate points, depending on their size. Varying our sampling intensity according to population size ultimately led to the sampling of 12 to $42($ mean $=24)$ beds from 9 of our 11 populations. The exceptions were Cold Pass, which was extremely limited in its spatial extent and was therefore sampled from just 2 beds (4 replicates each), and our volunteer site, which consisted of roughly 90 spatially isolated beds at the time of sampling. Our sampling effort at this latter site was much more intensive than at all other sites because we wished to determine the specific origin of a large proportion of the clones growing there. We randomly selected 42 beds from this population (Fig. 2), with up to seven replicate ramets collected per bed. For all sampling activities, we used a $15 \mathrm{~cm}$ diameter plastic corer to extract seagrass fragments 100 to $150 \mathrm{~mm}$ in length, which generally consisted of 3 to 5 shoots attached to a section of rhizome. Only a single section of rhizome was used for subsequent DNA analyses. We recorded the location of each collected fragment by using a hand-held GPS (Garmin International), except in volunteer beds where only the center of the bed was recorded. Samples were placed in labeled plastic bags, stored on ice in the field, and subsequently frozen in the laboratory prior to genetic analysis.

Genetic analyses. We extracted DNA from seagrass rhizomes using a standard CTAB (hexadecyltrimethyl-ammonium bromide)-based method (Saghai-Maroof et al. 1984, Rogers \& Bendich 1985, Doyle \& Doyle 1987), as described in Travis et al. (2002). Leaf tissue was omitted from the extractions in order to avoid contamination of seagrass DNA with that of epiphytic algae.

We constructed a multilocus genotype for each seagrass ramet on the basis of AFLPs generated according to the methods of Vos et al. (1995) as modified by Travis et al. (2004). This process involved 2 successive polymerase chain reactions (PCR): a selective preamplification, involving 1 selective nucleotide, and a more stringent selective restriction fragment amplification (SRFA), with 3 selective nucleotides. In all, 4 combinations of PCR primers were used to generate AFLP markers in 4 separate SRFA reactions. A single primer containing a restriction site for EcoRI and the selective nucleotides ACG was paired with each of 4 primers containing a restriction site for $\mathrm{MseI}$ and the selective nucleotides ACC, AGG, ACA or ACG.

We searched for identical multilocus genotypes among replicate seagrass ramets collected within populations in order to compare clonal richness and diversity among populations and to reduce the overall data set down to the level of genets for an evaluation of genetic diversity and population structure. We assessed the validity of this approach by calculating the random probability of separate clones sharing all population-specific markers in common. This was done by taking the product, over all loci, of the individual-locus probabilities, each calculated as the sum of squares of the expected haplotype (i.e. marker presence or absence) frequencies. In order to be conservative, we included all ramets in this assessment, with no a priori assumptions regarding clone identities.

We computed overall clonal richness for each population, $R$, as $(G-1) /(N-1)$, where $G=$ number of genotypes (genets) detected, and $N=$ number of ramets sampled (Dorken \& Eckert 2001). This measure com- 


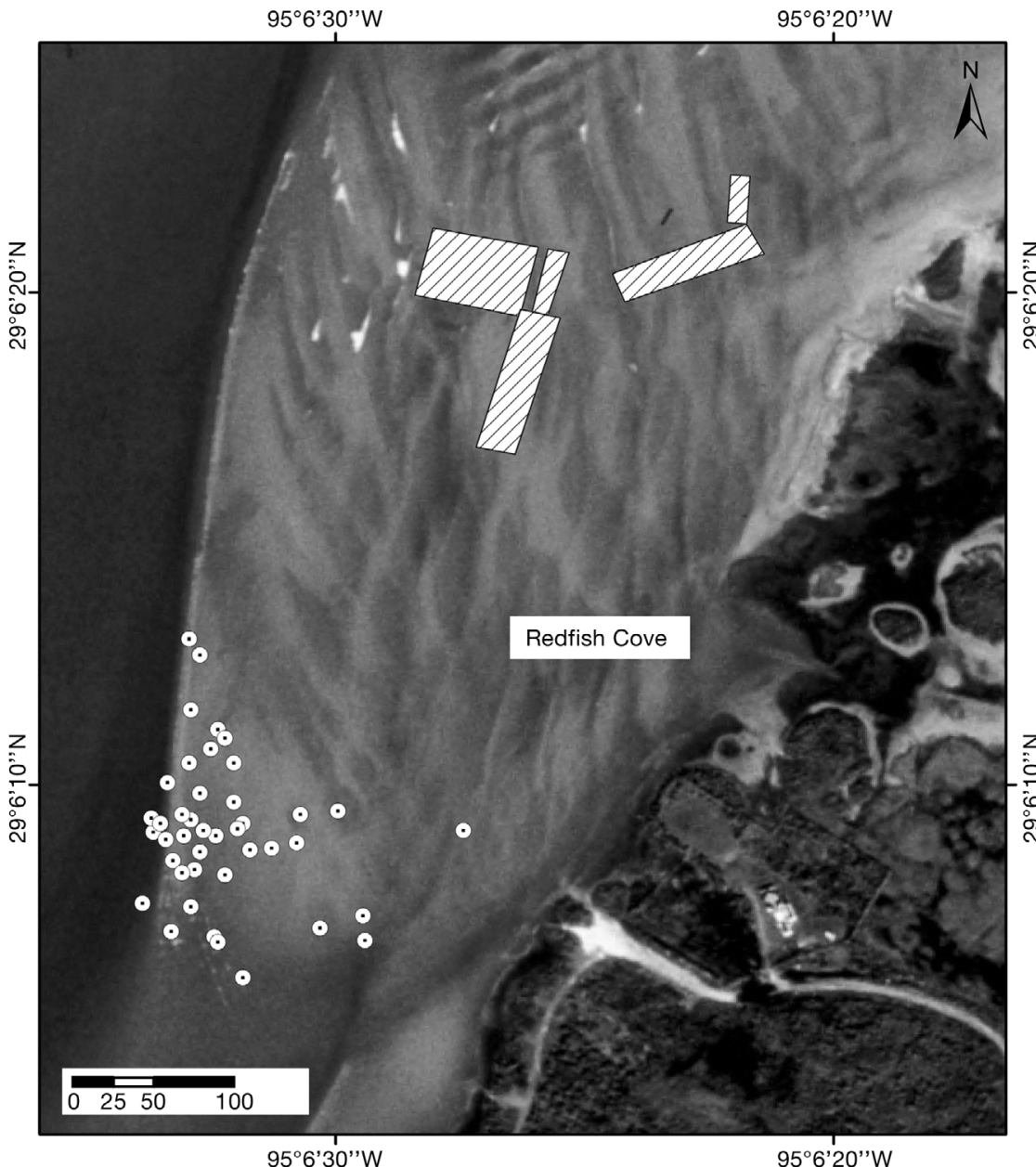

Fig. 2. Halodule wrightii. Aerial photograph showing the spatial distribution of planted seagrass meadows (hatched rectangles) and 42 sampled volunteer beds (circles) relative to shoreline at Redfish Cove, Galveston Bay, Texas

ment at each marker locus was equivalent to the frequency of homozygous recessive genotypes. Because this approach is particularly sensitive to nonrandom mating (i.e. inbreeding), we also characterized genetic diversity as the complement of the average proportion of markers shared between pairs of ramets, which we will denote as $1-S$.

Population differentiation was estimated using the Bayesian approach of Holsinger et al. (2002), which yields traditional $F$-statistics equivalent to the $\theta$-statistic of Weir \& Cockerham (1984), and ranges from 0 to 1 . Unlike traditional F-statistics, this method does not require allelic frequencies to adhere to Hardy-Weinberg expectations because it automatically adjusts for the possible occurrence of inbreeding. This method also provides lower $95 \%$ confidence intervals by which the significance of observed levels of differentiation can be judged. F-statistics were used to assess possible isolation-by-distance among our 4 natural sites by regressing pairwise values of $\theta /(1-\theta)$ on linear distances of coastline separating the sites, as recommended by Rousset (1997).

We determined the most likely population of origin for each ramet sampled from our volunteer population by using the DOH program of

pensates for the upward bias of simple calculations of $G / N$ when clonal richness and sample size are low, and ranges from 0 to 1 . We used a bootstrapping procedure in our estimates of population-level $R$, in order compensate for the effects of varying sample sizes. An average value of $R$ was calculated for each population from 100 random draws of 10 ramets each. For comparisons of clonal diversity at the scale of individual beds within populations, we used weighted averages of both $R$ and the complement of the Simpson index, $1-D$ (Pielou 1969). The latter statistic also ranges from 0 to 1 , but incorporates both clonal richness and evenness.

Genetic diversity was assessed from the entire group of genets identified within each population on the basis of average heterozygosities and proportions of polymorphic alleles (Hartl \& Clark 1997). Average heterozygosities were estimated using the HardyWeinberg equation, under the assumption that the frequency of individuals lacking an amplified frag-
Paetkau et al. (1995). This analysis assigned a probability to each volunteer ramet of it being drawn from each of the 10 potential source populations included in this study, based on their corresponding allele frequencies.

\section{RESULTS}

We developed 98 AFLP markers from 4 primer combinations for characterizing genetic variation in Halodule wrightii. Across all sampling sites, 68 (69\%) of these markers were variable. Given the frequencies of these markers within populations, the random probability, averaged over all populations, that 2 ramets with identical multilocus genotypes came from different genetic individuals was $1.297 \times 10^{-2}$.

The overall level of clonal richness varied considerably among populations, with average bootstrap esti- 
mates ranging from 54 to $82 \%$ (Table 2). This entire range of variation was represented among the natural populations (mean $R=0.656$ ), while the restored populations varied to a lesser degree with between 66 and $82 \%$ of ramets representing distinct genets (mean $R=$ 0.752 ). Overall clonal richness of the volunteer population was relatively high at $R=0.814$.

With the exception of the volunteer site, mean clonal richness and diversity within beds (measured for 5 populations) tended to run somewhat higher than did overall clonal richness, with an average of 63 to $100 \%$ of the ramets representing distinct clones (Table 2). Within populations, clonal richness at the scale of beds ( 3 to $5 \mathrm{~m}$ ) ran 4 to $22 \%$ higher than at the population scale (mean $R=0.628$ to 1.000 versus 0.606 to 0.821 , respectively), except at the volunteer site where clonal richness within beds was $10 \%$ less than at the population level (mean $R=0.726$ versus 0.814 ).

A relatively low percentage of clones were shared among the 4 populations at Redfish Cove that were restored in 1999 with plant materials from 4 separate donor sites (Table 3 ). The percentage of clones shared ranged from 8 to $24 \%$ (mean $=14 \%$ ).

Although genetic diversity was low overall for both the mean proportion of polymorphic loci $(0.20)$ and average heterozygosity (0.07), comparisons among the populations revealed comparatively high genetic diver- sity for the volunteer seagrass population near Redfish Cove (Table 2). Volunteers exhibited $45 \%$ polymorphic loci, which was nearly $70 \%$ higher than the next highest population (Dana Cove) and nearly 170\% higher than the mean for all other populations. The results were less striking for average heterozygosity, although the overall pattern was similar: the volunteers exhibited an average heterozygosity of 0.116 , which was $26 \%$ higher than the Dana Cove population and $77 \%$ higher than the mean for all other populations. Mean dissimilarities $(1-S)$ within populations were sufficiently low overall to be considered uninformative.

A comparison of restored populations with their original donor populations showed them to be no less genetically diverse (Table 2) based on paired-sample $t$-tests (statistics not shown). These comparisons included donor populations and restorations originating from Christmas Bay, East Matagorda Bay, Matagorda Bay (Port O'Connor), and the Redfish Cove population restored in 1994 from materials collected in Matagorda Bay (Palacios). Mean proportions of polymorphic loci were 0.176 for the restored populations versus 0.184 for the donor populations, and average heterozygosities were 0.069 for the restored populations versus 0.072 for the donor populations.

Genetic differentiation across the $170 \mathrm{~km}$ of coastline encompassed by our study was small to moderate

Table 2. Halodule wrightii. Clonal and genetic diversity of populations from SE Texas (volunteer = naturally recruited) sampled in 2001 and 2002. For restored populations at Redfish Cove, year of planting and original donor site are given (CB: Christmas Bay; EMB: East Matagorda Bay; MBO: Matagorda Bay near Port O'Connor; MBP: Matagorda Bay near Palacios; 1994 in parentheses: material donated from Redfish Cove planting in 1994). N: sample size (ramets); $R$ : clonal richness; $1-D$ : complement of Simpson (clonal) diversity index; $\langle P\rangle$ : proportion of polymorphic loci; $\langle H\rangle$ : average heterozygosity; $1-S$ : complement of average proportion of markers shared between pairs of clones. na: not analyzed

\begin{tabular}{|c|c|c|c|c|c|c|c|c|c|}
\hline \multirow{2}{*}{$\begin{array}{l}\text { Site } \\
\text { (Population) }\end{array}$} & \multirow[t]{2}{*}{ Bed type } & \multirow{2}{*}{$\begin{array}{c}\text { Overall } \\
\mathrm{N}\end{array}$} & \multirow{2}{*}{$\begin{array}{c}\text { Overall } \\
R\end{array}$} & \multicolumn{3}{|c|}{ - Average within beds } & \multirow[t]{2}{*}{$<P>$} & \multirow[t]{2}{*}{$<H>$} & \multirow{2}{*}{$\begin{array}{c}1-S \\
\text { (avg.) }\end{array}$} \\
\hline & & & & $\mathrm{N}$ & $R$ & $1-D$ & & & \\
\hline Volunteers & Volunteer & 198 & 0.814 & 4.8 & 0.726 & 0.863 & 0.449 & 0.1161 & 0.0258 \\
\hline $\begin{array}{c}\text { Redfish Cove } \\
1999 \text { (CB) }\end{array}$ & Restored & 17 & 0.733 & na & na & na & 0.143 & 0.0580 & 0.0214 \\
\hline $\begin{array}{r}\text { Redfish Cove } \\
1999 \text { (EMB) }\end{array}$ & Restored & 52 & 0.763 & 2.5 & 0.925 & 0.950 & 0.184 & 0.0730 & 0.0231 \\
\hline $\begin{array}{r}\text { Redfish Cove } \\
1999(\mathrm{MBO})\end{array}$ & Restored & 18 & 0.751 & na & na & na & 0.153 & 0.0628 & 0.0262 \\
\hline $\begin{array}{r}\text { Redfish Cove } \\
1999 \text { (1994) }\end{array}$ & Restored & 47 & 0.824 & na & na & na & 0.224 & 0.0819 & 0.0256 \\
\hline $\begin{array}{r}\text { Redfish Cove } \\
1994 \text { (MBP) }\end{array}$ & Restored & 36 & 0.663 & na & na & na & 0.204 & 0.0774 & 0.0255 \\
\hline Dana Cove & Restored & 33 & 0.778 & 2.7 & 0.944 & 0.972 & 0.265 & 0.0924 & 0.0277 \\
\hline Cold Pass & Natural & 8 & na & na & na & na & 0.061 & 0.0280 & 0.0149 \\
\hline Christmas Bay & Natural & 28 & 0.821 & 2.2 & 1.000 & 1.000 & 0.214 & 0.0862 & 0.0289 \\
\hline $\begin{array}{l}\text { East Matagorda } \\
\text { Bay }\end{array}$ & Natural & 55 & 0.606 & 3.5 & 0.628 & 0.731 & 0.173 & 0.0638 & 0.0199 \\
\hline $\begin{array}{l}\text { Matagorda Bay } \\
\text { (near Port O'Conn }\end{array}$ & $\begin{array}{l}\text { Natural } \\
\text { nor) }\end{array}$ & 16 & 0.541 & na & na & na & 0.143 & 0.0589 & 0.0165 \\
\hline
\end{tabular}


Table 3. Halodule wrightii. Proportion of clones shared among restorative plantings established from separate donor populations at Redfish Cove during 1999. 1994: material donated from Redfish Cove planting in 1994. Names of cities nearby in parentheses

\begin{tabular}{|c|c|c|c|c|}
\hline & $\begin{array}{c}\text { Christmas } \\
\text { Bay }\end{array}$ & $\begin{array}{c}\text { East Matagorda } \\
\text { Bay }\end{array}$ & $\begin{array}{l}\text { Matagorda Bay } \\
\text { (Port O'Connor) }\end{array}$ & $\begin{array}{l}\text { Redfish Cove } \\
1994 \text { (Palacios) }\end{array}$ \\
\hline Christmas Bay & $\mathrm{x}$ & & & \\
\hline $\begin{array}{l}\text { East Matagorda } \\
\text { Bay }\end{array}$ & 0.083 & $\mathrm{x}$ & & \\
\hline $\begin{array}{l}\text { Matagorda Bay } \\
\text { (Port O'Connor) }\end{array}$ & 0.148 & 0.167 & $\mathrm{x}$ & \\
\hline $\begin{array}{l}\text { Redfish Cove } \\
1994 \text { (Palacios) }\end{array}$ & 0.150 & 0.237 & 0.200 & $\mathrm{x}$ \\
\hline
\end{tabular}

at an overall level of $\theta=0.052$, although this level was slightly higher when only natural populations were included in the comparison at $\theta=0.062$ (unless otherwise noted, all $\theta$-values were significantly different from zero; Table 4). An analysis of isolation-bydistance, which included only the natural populations sampled at Cold Pass, Christmas Bay, East Matagorda Bay, and Matagorda Bay (Port O'Connor), revealed a significant relationship between genetic and geographic distance (Fig. 3; matrix correlation, $r=0.822$, Mantel's $t=1.89, \mathrm{p}=0.029$ ). Genetic distances for this analysis ranged from $\theta=0.041$ (Cold Pass versus Christmas Bay at a geographic distance of $6 \mathrm{~km}$ ) to $\theta=$ 0.169 (Cold Pass versus Matagorda Bay at a distance of $147 \mathrm{~km})$.

An examination of genetic differentiation between the seagrass populations restored at Redfish Cove in 1999 and their original donor populations indicates their rapid divergence (Table 4). The average level of differentiation between paired restored versus donor populations was $\theta=0.068$. Gene flow among the restored populations would appear to be a cause of this rapid differentiation, as they were considerably less differentiated from each other $(\theta=0.029)$ than were their original group of donor populations $(\theta=0.077)$, and in one case the pairwise level of differentiation was not significantly different from zero (for the 1999 planting from East Matagorda Bay versus the 1994 planting from Matagorda Bay near Palacios).

A multilocus genotype assignment test of the most likely population(s) of origin for the volunteer beds near Redfish Cove indicated a close affinity with the nearby restored populations (Fig.4). Over $70 \%$ of the volunteer clones (of which 91 were identified) were assigned to the restored populations at Redfish Cove, with the majority of these ( $57 \%$ ) being assigned specifically to the 1994 population planted with donor material collected from Matagorda Bay near Palacios and the 1999 population for which the 1994 plantings served as a donor. Another $12 \%$ of the volunteers were assigned to the restored population at Dana Cove, which altogether accounted for $83 \%$ of the samples. Interestingly, only 2 and $7 \%$ of the volunteers were assigned to the nearby Cold Pass and Christmas Bay populations, respectively.

\section{DISCUSSION}

Our results demonstrate that natural populations of Halodule wrightii vary considerably in clonal richness. Wide variation in clonal diversity among populations has been noted for other seagrass species, ranging

Table 4. Halodule wrightii. Matrix of genetic distances $(\theta)$ among populations in SE Texas (dates given are year of planting). RC: Redfish Cove; CB: Christmas Bay; EMB: East Matagorda Bay; MBO: Matagorda Bay near Port O'Connor; MBP: Matagorda bay near Palacios; DC: Dana Cove; CP: Cold Pass; 1994 in parentheses: material donated from Redfish Cove planting in 1994. Original donor sites given in parentheses. Asterisks indicate level of differentiation that is significantly different from zero based on lower $95 \%$ confidence interval

\begin{tabular}{|c|c|c|c|c|c|c|c|c|c|c|c|}
\hline & $\begin{array}{l}\text { Volun- } \\
\text { teers }\end{array}$ & $\begin{array}{l}\text { RC } 1999 \\
\quad(\mathrm{CB})\end{array}$ & $\begin{array}{c}\text { RC } 1999 \\
(\text { EMB) }\end{array}$ & $\begin{array}{c}\mathrm{RC} 1999 \\
(\mathrm{MBO})\end{array}$ & $\begin{array}{c}\text { RC } 1999 \\
(1994)\end{array}$ & $\begin{array}{c}\text { RC } 1994 \\
\text { (MBP) }\end{array}$ & DC & $\mathrm{CP}$ & $\mathrm{CB}$ & EMB & $\mathrm{MBO}$ \\
\hline Volunteers & $\mathrm{x}$ & & & & & & & & & & \\
\hline RC 1999 (CB) & $0.036^{*}$ & $\mathrm{x}$ & & & & & & & & & \\
\hline RC 1999 (EMB) & $0.037^{*}$ & $0.053^{*}$ & $\mathrm{x}$ & & & & & & & & \\
\hline RC 1999 (MBO) & $0.015^{*}$ & $0.024^{*}$ & $0.028^{*}$ & $\mathrm{x}$ & & & & & & & \\
\hline RC 1999 (1994) & $0.038^{*}$ & $0.069^{*}$ & $0.020^{*}$ & $0.037^{*}$ & $\mathrm{x}$ & & & & & & \\
\hline RC 1994 (MBP) & $0.018^{*}$ & $0.050^{*}$ & 0.017 & $0.020^{*}$ & $0.020^{*}$ & $\mathrm{x}$ & & & & & \\
\hline $\mathrm{DC}$ & $0.065^{*}$ & $0.102^{*}$ & $0.095^{*}$ & $0.066^{*}$ & $0.096^{*}$ & $0.077^{*}$ & $\mathrm{x}$ & & & & \\
\hline $\mathrm{CP}$ & $0.031^{*}$ & $0.099^{*}$ & $0.053^{*}$ & $0.104^{*}$ & $0.033^{*}$ & $0.056^{*}$ & $0.045^{*}$ & $\mathrm{x}$ & & & \\
\hline $\mathrm{CB}$ & $0.101^{*}$ & $0.086^{*}$ & $0.102^{*}$ & $0.076^{*}$ & $0.085^{*}$ & $0.094^{*}$ & $0.128^{*}$ & $0.041^{*}$ & $\mathrm{x}$ & & \\
\hline EMB & $0.074^{*}$ & $0.103^{*}$ & $0.104^{*}$ & $0.074^{*}$ & $0.062^{*}$ & $0.085^{*}$ & $0.099^{*}$ & $0.094^{*}$ & $0.049^{*}$ & $\mathrm{x}$ & \\
\hline $\mathrm{MBO}$ & $0.081^{*}$ & $0.125^{*}$ & $0.082^{*}$ & $0.061^{*}$ & $0.080^{*}$ & $0.086^{*}$ & $0.122^{*}$ & $0.169^{*}$ & $0.101^{*}$ & $0.064^{*}$ & $\mathrm{x}$ \\
\hline
\end{tabular}




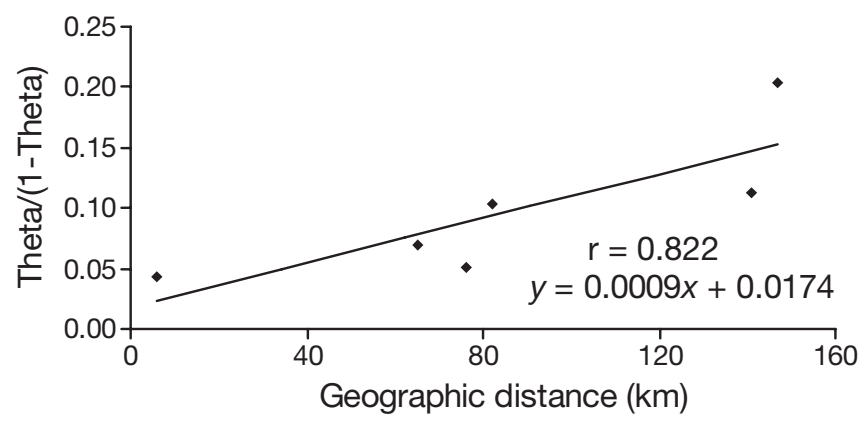

Fig. 3. Halodule wrightii. Isolation-by-distance of seagrass in the NW Gulf of Mexico. Genetic distance on y-axis $=\theta /(1-\theta)$

from near monoclonality (e.g. Proccacini et al. 1996, Waycott et al. 1996, Reusch et al. 1999) to maximal clonal diversity (e.g. Reusch 2002, Olsen et al. 2004). Clonal diversity can be affected by population age and level of disturbance (Reusch et al. 1999, Jover et al. 2003). The variation in clonal richness that we observed for our natural populations, in the 0.54 to 0.82 range, is unlikely to be due to variation in disturbance levels, since all 3 of the populations for which overall richness was measured occupied sheltered bays and channels. It is interesting to note, however, that the 2 populations with the lowest population-level clonal diversity (East Matagorda Bay and Matagorda Bay near Palacios) may have experienced the lowest levels of human disturbance over the past century, since they are the most isolated from major ports and human population centers. In particular, our observation that $>50 \%$ of the ramets sampled at East Matagorda Bay

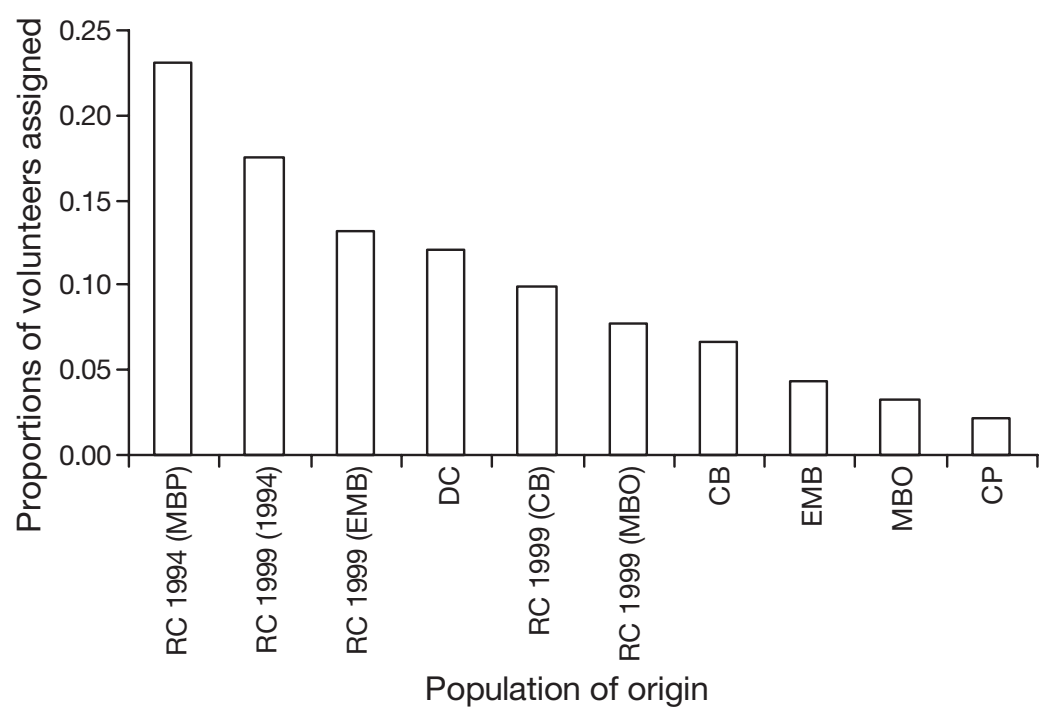

Fig. 4. Halodule wrightii. Possible populations of origin for volunteer clones growing near Redfish Cove in the Galveston Bay system. CB: Christmas Bay; CP: Cold Pass; DC: Dana Cove; EMB: East Matagorda Bay; MBO: Matagorda Bay near Port O'Connor; MBP: Matagorda Bay near Palacios; RC: Redfish Cove. Original donor sites given in parentheses belonged to just 4 of 22 clones suggests that this may constitute a sufficiently stable environment to have allowed individual clones to achieve quite old ages, and that the recruitment of propagules may be sufficiently limited in sheltered bays to allow competitively superior clones to dominate over time (Eriksson 1993).

Estimates of clonal richness and diversity at the scale of individual seagrass beds were consistently higher than clonal richness at the population scale, except for a recently established volunteer site. The latter exception was likely to have been due to a much higher sampling intensity at the level of individual beds, which would have increased the probability of multiple sampling from identical clones, thus reducing estimates of clonal richness at this scale. Notably, of the remaining 4 populations, Christmas Bay was found to be multiclonal and maximally diverse for all sampled beds. Clonal diversity was also found to be $100 \%$ during a broader genetic survey of Halodule wrightii at Christmas Bay, which included 40 samples collected over a scale of $30 \mathrm{~m}$ by Angel (2002). Davis et al. (1999) found reduced clonal richness at the population scale in Thalassia testudinum, which they explained via a natural process of guerilla growth followed by the breakdown of rhizomatous connections among ramets, and Ruggiero et al. (2005) described Cymodocea nodosa clones with scattered ramets separated by up to $60 \mathrm{~m}$. This process could help explain why our volunteer site was so highly diverse at the population scale, since most of the beds would have begun to establish themselves just 1 or 2 yr prior to our study and would have had little time for clonal spread.

A second form of fragmentation could involve the rafting of vegetative fragments away from their founding clone and their subsequent establishment in other areas, as suggested for Thalassia testudinum (Waycott \& Barnes 2001) and Zostera marina (Reusch 2002). This process may have been facilitated at our restored sites by rather expansive areas of bare substrate, allowing currents to carry seagrass fragments over substantial distances before becoming lodged amongst the vegetation of existing beds. At the local level, seedling recruitment may have promoted higher clonal diversity, since Halodule wrightii seeds are produced beneath the sediment surface and are negatively buoyant (McMillan 1985). Gene flow via seeds and pollen is generally restricted to $<15 \mathrm{~m}$ for other seagrass species such as Z. marina (Ruckelshaus 1996), and Cymodocea nodosa (Ruggiero et al. 
2005), except where very strong currents are known to prevail (Muñiz-Salazar et al. 2005).

Genetic diversity estimated from the total group of clones identified within each natural population was quite low compared to other widespread, outcrossing plant species, which typically exhibit average heterozygosities 2 to 3 times greater than we observed (Hamrick \& Godt 1990). Genetic diversity has been shown to vary widely among seagrass species, from near zero in Amphibolis antarctica (Waycott et al. 1996) to extremely high in Zostera marina (Ruckelshaus 1998). Our study was conducted over a relatively limited span of coastline $(170 \mathrm{~km})$, much of which has obviously suffered from relatively high levels of human disturbance (Pulich \& White 1991, Hammerstrom et al. 1998) caused by proximity to major coastal cities such as Houston and Corpus Christi, Texas. It is likely that population declines, fragmentation, and perhaps even extinction and recolonization have led to population bottlenecks and a loss of genetic diversity (Reusch 2002, Muñiz-Salazar et al. 2005). Additional studies encompassing a greater proportion of the geographic range of Halodule wrightii will be needed to confirm this. On the other hand, the nearly complete lack of genetic diversity within our Cold Pass population, which consisted of 2 small seagrass beds with just $6 \%$ polymorphic loci and an average heterozygosity of 0.028, gives a preliminary indication of the effect that small population size can have through founder effects and random drift. It is noteworthy that the Cold Pass population is immediately adjacent to Christmas Bay, which has a relatively high genetic diversity. While our genetic diversity estimates for the Christmas Bay population agree with those found by Angel (2002) using RAPD markers, she found a considerably higher average heterozygosity of 0.136 for a $H$. wrightii population sampled from Laguna Madre near Corpus Christi, which may be an indication of historically higher levels of genetic diversity in $H$. wrightii.

A comparison of the 4 natural populations in our study revealed a clear pattern of genetic isolation-bydistance, with pairwise $\theta$-values ranging 4 -fold (from 0.041 to 0.169 ) over just $150 \mathrm{~km}$. This pattern may serve as an indication of the fragmentation of what was once a single continuous population occupying the coast of Texas, with the subsequent genetic isolation of surviving meadows, as seen in Zostera noltii (Diekmann et al. 2005). Isolation-by-distance is somewhat uncommon in seagrasses and is highly region-specific (Olsen et al. 2004, Muñiz-Salazar et al. 2005 and references therein), with some species displaying an almost complete lack of population differentiation over as much as $2700 \mathrm{~km}$ (Waycott \& Barnes 2001). Given the proper set of conditions, however, significant differentiation can occur over distances as small as $5 \mathrm{~km}$ (Olsen et al. 2004). Those species that exhibit significant levels of differentiation often do so in a seemingly random fashion, most often attributed to stochastic factors affecting dispersal, such as prevailing current patterns (Procaccini et al. 1996) or geologic history (Olsen et al. 2004).

Seagrass restorations conducted in Galveston Bay from 1994 to 2000 appear to have established a selfrecruiting set of populations with genetic characteristics similar to those of natural populations in the region. The single population that was successfully restored to Dana Cove between 1995 and 2000, as well as the various populations restored to Redfish Cove during 1994 and 1999, exhibited levels of clonal and genetic diversity that were medium to high compared to those of nearby natural populations which have probably experienced varying levels of disturbance (see first paragraph of 'Discussion'). An important caveat here is that our estimates of average heterozygosity may have been inflated at the Redfish Cove site, if any of the populations consisted of a nonequilibrium assortment of original donor materials mixed with clones that had recently rafted in and become established from neighboring plantings.

The Dana Cove population at the NE edge of our sampling range was moderately differentiated from all other populations, which was not surprising considering that much of the donor material for this population was taken from Laguna Madre, approximately $300 \mathrm{~km}$ to the SW. Nevertheless, the average level of differentiation between Dana Cove and all other populations was less than that between several of the natural populations in our survey, which suggests that it is receiving gene flow from nearby populations.

Interestingly, the various restorative plantings near Redfish Cove are undergoing rapid genetic convergence, with overall differentiation among them at just 0.03, whereas the overall level of differentiation among their original donor populations was 0.08 . On average, the level of differentiation between these restored populations and their respective populations of origin was 0.07 . That the genetic homogenization of the restored populations at Redfish Cove is due, at least in part, to the rafting of clonal fragments is evidenced by the sharing of clonal genotypes among independent plantings, which affected an average of $16 \%$ of the clones sampled. The rafting of Halodule wrightii fragments was first noted by Zieman (1987), who examined seagrass export of floating material, and was actually incorporated into the restoration strategy of Clark (1989), who captured rafting shoots of $H$. wrightii in arrays of emergent stakes and monitored their growth. Such rafting may also help to account for the loss of genetic structure that has been shown to occur fairly rapidly among seagrass populations when new substrate is readily avail- 
able for colonization (Alberto et al. 2001), as was the case for our Redfish Cove site. This process may have been further facilitated by the presence of seeds attached to rafting fragments, which is a major form of dispersal in Zostera marina (Reusch 2001). In theory, because $H$. wrightii flowers and seeds are found at the sediment-water interface (McMillan 1985), any disturbance that releases live plant fragments could aid the dispersal of seeds.

Not only are the restored populations at Redfish Cove self-recruiting, but they also appear to be providing a steady supply of immigrants to a nearby volunteer population, as indicated by a multilocus assignment test. The mixing of genetic stock from multiple donor populations within the volunteer site has perhaps helped to increase overall genetic diversity well beyond that of most other populations in the region, both natural and restored, with the proportion of polymorphic loci and average heterozygosity elevated by 70 and $26 \%$, respectively, above the next most diverse population, Dana Cove. However, because genotype assignment tests indicated that this site was established from a random assortment of recruits from the various restorative plantings at Redfish Cove, many if not most of which may have rafted in as clone fragments, this population may not yet have achieved Hardy-Weinberg equilibrium frequencies. If this is the case, then the use of dominant markers such as AFLPs would tend to overestimate average heterozygosities. This issue will only be resolvable through the use of codominant markers such as microsatellites, which have yet to be developed for Halodule wrightii.

A growing number of studies are recognizing the importance of clonal richness and diversity in determining both the fitness of transplanted individuals and populations of seagrasses, as well as the persistence of restored seagrasses. This is a serious issue for restoration, since plant materials gathered for transplantation without the benefit of genetic data have been shown in some instances to harbor reduced genetic diversity relative to natural populations (e.g. Williams \& Orth 1998, Williams 2001). Fortunately, our results indicate that the populations restored to Galveston Bay have not suffered such a fate, which may be related to designing multiple sites of origin into the restoration plan. Indeed, the mixing of plant materials from at least 3 donor sites is now the recommended policy for Zostera marina restorations in California in order to promote natural levels of genetic diversity (Williams 2001). Future restoration efforts throughout the range of Halodule wrightii should continue to consider acquiring plant materials from multiple donor sites, but only after it has been determined from genetics studies that they harbor natural levels of clonal and genetic diversity and that genetic differentiation among them is not too extreme.
Acknowledgements. Thanks to J. Kemmerer and S. Stevens (National Wetlands Research Center) and to J. Doerr, S. King, J. Salas, and S. Hillen (National Marine Fisheries Service, Galveston Laboratory) for field operations and laboratory assistance. Funds for this project were provided by the NOAA Restoration Center, Texas Parks and Wildlife Department, and Texas Natural Resource Conservation CommissionGalveston Bay Estuary Program. Any use of trade, product, or firm names is for descriptive purposes only and does not imply endorsement by the US Government.

\section{LITERATURE CITED}

Alberto F, Mata L, Santos R (2001) Genetic homogeneity in the seagrass Cymodocea nodosa at its northern Atlantic limit revealed through RAPD. Mar Ecol Prog Ser 221:299-301

Angel RK (2002) Genetic diversity of Halodule wrightii using random amplified polymorphic DNA. Aquat Bot 74:165-174

Clark P A (1989) Seagrass restoration: a non-destructive approach. In: Webb, FJ Jr (ed) Proc 16th Annu Conf Wetlands Restoration and Creation. Hillsborough Community College, Tampa, FL, p. 57-70

Davis JL, Childers DL, Kuhn DN (1999) Clonal variation in a Florida Bay Thalassia testudinum meadow: molecular genetic assessment of population structure. Mar Ecol Prog Ser 186:127-136

Diekmann OE, Coyer JA, Ferreira J, Olsen JL, Stam WT, Pearson GA, Serrão EA (2005) Population genetics of Zostera noltii along the west Iberian coast: consequences of small population size, habitat discontinuity and nearshore currents. Mar Ecol Prog Ser 290:89-96

Dorken, ME, Eckert CG (2001) Severely reduced sexual reproduction in northern populations of a clonal plant, Decodon verticillatus (Lythraceae). J Ecol 89:339-350

Doyle JJ, Doyle JL (1987) A rapid DNA isolation procedure for small quantities of fresh leaf tissue. Phytochem Bull 19: $11-15$

Duarte CM (2002) The future of seagrass meadows. Environ Conserv 29:192-206

Eriksson O (1993) Dynamics of genets in clonal plants. Trends Ecol Evol 8:313-316

Galveston Bay Foundation (2003) Seagrass restoration on Galveston Island. Final report to National Marine Fisheries Service. Galveston Bay Foundation, Webster, TX

Hämmerli A, Reusch TBH (2003) Genetic neighbourbood of clone structures in eelgrass meadows quantified by spatial autocorrelation of microsatellite markers. Heredity 91: $448-455$

Hammerstrom K, Sheridan P, McMahan G (1998) Potential for seagrass restoration in Galveston Bay, Texas. Tex J Sci 50: $35-50$

Hamrick JL Godt MJW (1990) Isozyme diversity in plant species. In: Brown AHD, Clegg T, Kahler AL, Weir BS (eds) Plant population genetics, breeding and genetic resources. Sinauer Associates, Sunderland, MA, p 43-63

Hartl DL, Clark AG (1997) Principles of population genetics, 3rd edn. Sinauer Associates, Sunderland, MA

Heck KL Jr, Hays CG, Orth RJ (2003) Critical evaluation of the nursery role hypothesis for seagrass meadows. Mar Ecol Prog Ser 253:123-136

Hemminga MA, Duarte CM (2000) Seagrass ecology. Cambridge University Press, Cambridge

Holsinger KE, Lewis PO, Dey DK (2002) A Bayesian approach to inferring population structure from dominant markers. Mol Ecol 11:1157-1164

Hughes AR, Stachowicz JJ (2004) Genetic diversity enhances 
the resistance of a seagrass ecosystem to disturbance. Proc Natl Acad Sci USA 101:8998-9002

Jover MA, del Castillo-Agudo L, Garcia-Carrascosa M, Segura J (2003) Random amplified polymorphic DNA assessment of diversity in western Mediterranean populations of the seagrass Posidonia oceanica. Am J Bot 90:364-369

Kennish MJ (1986) Ecology of estuaries, Vol 2. CRC Press, Boca Raton, FL

Krauss SL, Koch JM (2004) Rapid genetic delineation of provenance for plant community restoration. J Appl Ecol 41: $1162-1173$

Kusler JA, Kentula ME (1989) Wetland creation and restoration: the status of the science. EPA/600/3-89/038. US Environmental Protection Agency, Environmental Research Laboratory, Corvallis, OR

Les DH (1988) Breeding systems, population structure and evolution in hydrophilous angiosperms. Ann MO Bot Gard 75: 819-835

Lieth, H, Whittaker, RH (1975) Primary productivity of the biosphere. Springer-Verlag, Berlin

McMillan, C (1985) The seed reserve for Halodule wrightii, Syringodium filiforme, and Ruppia maritima in Laguna Madre, Texas. Contrib Mar Sci 28:141-149

Montalvo AM, Williams SL, Rice KJ, Buchmann SL and 5 others (1997) Restoration biology: a population biology perspective. Restor Ecol 5:277-290

Muñiz-Salazar R, Talbot SL, Sage GK, Ward DH, GabelloPasini A (2005) Population genetic structure of annual and perennial populations of Zostera marina L. along the Pacific coast of Baja California and the Gulf of California. Mol Ecol 14:711-722.

Olsen JL, Stam WT, Coyer JA, Reusch TBH and 14 others (2004) North Atlantic phylogeography and large-scale population differentiation of the seagrass Zostera marina L. Mol Ecol 13:1923-1941

Paetkau D, Calvert W, Sterling I, Strobeck C (1995) Microsatellite analysis of population structure in Canadian polar bears. Mol Ecol 4:347-354

Pielou EC (1969) An introduction to mathematical ecology. Wiley-Interscience, New York

Procaccini G, Piazzi L (2001) Genetic polymorphism and transplantation success in the Mediterranean seagrass Posidonia oceanica. Restor Ecol 9:332-338

Procaccini G, Alberte RS, Mazzella L (1996) Genetic structure of the seagrass Posidonia oceanica in the Western Mediterranean: ecological implications. Mar Ecol Prog Ser 140: $153-160$

Pulich W, White W (1991) Decline of submerged vegetation in the Galveston Bay system: chronology and relationships to physical processes. J Coast Res 7:1125-1138

Reusch TBH (2001) New markers - old questions: population genetics of seagrasses. Mar Ecol Prog Ser 211:261-274

Reusch TBH (2002) Microsatellites reveal high population connectivity in eelgrass (Zostera marina) in two contrasting coastal areas. Limnol Oceanogr 47:78-85

Reusch TBH, Boström C, Stam WT, Olsen JL (1999) An ancient eelgrass clone in the Baltic Sea. Mar Ecol Prog Ser 183: 301-304

Reusch TBH, Ehlers A, Hämmerli A, Worm B (2005) Ecosystem recovery after climatic extremes enhanced by genotypic diversity. Proc Natl Acad Sci USA 102:2826-2831

Rogers SO, Bendich AJ (1985) Extraction of DNA from milligram amounts of fresh, herbarium, and mummified plant tissue. Plant Mol Biol 5:69-76

Rousset F (1997) Genetic differentiation and estimation of gene flow from F-statistics under isolation by distance. Genetics 145:1219-1228

Editorial responsibility: Howard I. Browman (Associate Editor-in-Chief), Storebø, Norway
Ruckelshaus MH (1996) Estimation of genetic neighborhood parameters from pollen and seed dispersal in the marine angiosperm Zostera marina L. Evolution 50:856-864

Ruckelshaus MH (1998) Spatial scale of genetic structure and an indirect estimate of gene flow in eelgrass, Zostera marina. Evolution 52:330-343

Ruggiero MV, Reusch, TBH, Procaccini G (2005) Local genetic structure in a clonal dioecious angiosperm. Mol Ecol 14: 957-967

Saghai-Maroof MA, Soliman DM, Jorgensen RA, Allard RW (1984) Ribosomal DNA spacer-length polymorphisms in barley: Mendelian inheritance, chromosomal location, and population dynamics. Proc Natl Acad Sci USA 81: 8014-8018

Schlapfer F, Schmid B (1999) Ecosystem effects of biodiversity: a classification of hypotheses and exploration of empirical results. Ecol Appl 9:893-912

Sheridan P (2002a) West Bay seagrass restoration demonstration project. Report to Texas Natural Resource Conservation Commission, Galveston Bay Estuary Program. National Marine Fisheries Service, Galveston, TX

Sheridan P (2002b) Seagrass planting in marsh terrace fields and monitoring seagrass survival and utilization by nekton. Report to Galveston Bay/APEX Barges Oil Spill Natural Resources Trustees. National Marine Fisheries Service, Galveston, TX

Sheridan P, McMahan G, Hammerstrom K, Pulich W Jr (1998) Factors affecting restoration of Halodule wrightii to Galveston Bay, Texas. Restor Ecol 6:144-158

Sheridan P, Henderson C, McMahan G (2003) Fauna of natural seagrass and transplanted Halodule wrightii (shoalgrass) beds in Galveston Bay, Texas. Restor Ecol 11:139-154

Short FT, Wyllie-Echeverria S (1996) Natural and humaninduced disturbance of seagrasses. Environ Conserv 23: $17-27$

Travis SE, Proffitt CE, Lowenfeld RC, Mitchell TW (2002) A comparative assessment of genetic diversity among differently-aged populations of Spartina alterniflora on restored versus natural wetlands. Restor Ecol 10:37-42

Travis SE, Proffitt CE, Ritland K (2004) Population structure and inbreeding vary with successional stage in created Spartina alterniflora marshes. Ecol Appl 14:1189-1202

van Andel J (1998) Intraspecific variability in the context of ecological restoration projects. Perspect Plant Ecol Evol Syst 1/2:221-237

Vos P, Hogers R, Bleeker M, Reijans M and 7 others (1995) AFLP: a new technique for DNA fingerprinting. Nucleic Acids Res 23:4407-4414

Waycott M, Barnes PA (2001) AFLP diversity within and between populations of the Caribbean seagrass Thalassia testudinum (Hydrocharitaceae). Mar Biol 139:1021-1028

Waycott M, Walker DI, James SH (1996) Genetic uniformity in Amphibolis antarctica, a dioecious seagrass. Heredity 76 : 578-585

Weir BS, Cockerham CC (1984) Estimation of F statistics for the analysis of population structure. Evolution 38:1358-1370

Williams SL (2001) Reduced genetic diversity in eelgrass transplantations affects both population growth and individual fitness. Ecol Appl 11:1472-1488

Williams SL, Orth RJ (1998) Genetic diversity and structure of natural and transplanted eelgrass populations in the Chesapeake and Chincoteague bays. Estuaries 21:118-128

Zedler JB (2000) Progress in wetland restoration ecology. Trends Ecol Evol 15:402-407

Zieman J C (1987) A review of certain aspects of the life, death, and distribution of seagrasses of the southeastern United States 1960-1985. Fla Mar Res Publ 42:77-88

Submitted: December 15, 2005; Accepted: February 28, 2006

Proofs received from author(s): August 30, 2006 